\title{
Response of Winter Wheat to Chloride Fertilization in Sandy Loam Soils
}

\author{
K. W. Freeman and K. Girma \\ Department of Plant and Soil Sciences, Oklahoma State University, \\ Stillwater, Oklahoma, USA \\ J. Mosali \\ Samuel Roberts Noble Foundation, Inc., Ardmore, Oklahoma, USA \\ R. K. Teal, K. L. Martin, and W. R. Raun \\ Department of Plant and Soil Sciences, Oklahoma State University, \\ Stillwater, Oklahoma, USA
}

\begin{abstract}
Chloride $(\mathrm{Cl})$ as a yield and growth-limiting nutrient has been the object of experimental attention for the last several decades. Long-term experiments were conducted from 1996 to 2002 at Hennessey and Perkins, Oklahoma to evaluate the response of winter wheat grain yield and nitrogen $(\mathrm{N})$ uptake to 0,15 and $30 \mathrm{~kg} \mathrm{Cl}$ $\mathrm{ha}^{-1}$ rates. A randomized complete block experimental design with three replications was used at both sites. Grain yield data were subjected to statistical analysis using SAS. Polynomial Orthogonal contrasts were used to detect trends in grain yield and $\mathrm{N}$ uptake to chloride levels. Chloride fertilizer significantly increased wheat grain yields in $50 \%$ of the site-year combinations (14 total site years), and the increases were more notable on the sandy loam soil included in this study.
\end{abstract}

Keywords: Calcium chloride, chloride, grain yield, winter wheat

Received 12 January 2005, Accepted 27 October 2005

Contribution from the Oklahoma Agricultural Experiment Station.

Address correspondence to W. R. Raun, Department of Plant and Soil Sciences, 044 North Ag Hall, Oklahoma State University, Stillwater, OK 74078 , USA. E-mail: wrr@ mail.pss.okstate.edu 


\section{INTRODUCTION}

Chloride $(\mathrm{Cl})$ is an essential plant nutrient involved in several processes taking place in the plant including osmotic regulation (Kafkafi and Xu 2002); photosynthesis by evolution of oxygen $\left(\mathrm{O}_{2}\right)$ in photosystem, enzyme activation, and transportation of other plant nutrients (Broyer et al. 1954; Ozanne, Woolley, and Broyer 1957; Grant, Lamond, and Mohr 2003); plant development; lodging prevention, and disease suppression (Wallace 1944; Engel, Bruebaker, and Emborg 1994). Chloride has also been found to control physiological leaf spotting in some winter and durum wheat varieties and barley (Smiley, uddin, et al., 1993; Engel, Bruebaker, and Emborg 2001).

As a yield-and growth-limiting nutrient, $\mathrm{Cl}$ has been the object of experimental attention for the past several decades. However, recent publications related to $\mathrm{Cl}$ nutrition contained contradicting reports, where some reported the importance of supplementing crops with this nutrient but others not. The latter conclusion arises from the fact that $\mathrm{Cl}$ is required by plants in a very small amount, and this amount can be obtained from the processes in the soil and the surrounding environments plus from fertilizers designed to supply crops with macronutrients such as potassium $(\mathrm{K})$ and calcium $(\mathrm{Ca})$ (e.g., $\mathrm{KCl}$ and $\mathrm{CaCl}_{2}$ ) (Carr, Martin, and Melchior 2001). These compounds contain some chloride that can be used by crops to satisfy their requirement. Annual chloride depositions of 13 to $40 \mathrm{~kg} \mathrm{ha}^{-1}$ in precipitation are common and may increase to more than $112 \mathrm{~kg} \mathrm{ha}^{-1}$ in coastal areas (Lamond and Leikam 2002). Because of the distance away from seawater high in $\mathrm{Cl}$, inland areas are known to receive much lower amounts of $\mathrm{Cl}$ in rainfall. Several of the current Cl-related research activities are focused on the benefits obtained from $\mathrm{Cl}$ in suppressing foliar and root diseases (Miller 1998; Miller and Jungman 1998; Engel and Grey 1991; Christensen and Brett 1985; Thomason et al. 2001) rather than on grain yield.

However, there are several research studies that demonstrate the importance of fertilizing crops with $\mathrm{Cl}$ in the United States and elsewhere to maintain grain yields, especially in soils where the soil $\mathrm{Cl}$ is low, such as sandy and sandy loam soils (Sillanpää 1982). According to Glant, McLaren, and Johnston (2001), soil Cl levels less than $36 \mathrm{~kg} \mathrm{ha}^{-1}$ in the top $0.6 \mathrm{~m}$ of soil are generally used as an indication of insufficient quantity, and a level of $36-72 \mathrm{~kg} \mathrm{ha}^{-1}$ is assumed to be adequate. Chloride response to yield follows the concept of response of crops to mobile nutrients. This means the yield can be related directly to the amount of $\mathrm{Cl}$, given that this nutrient is the most limiting one in the soil. It is also important to note that $\mathrm{Cl}$ is mobile and subject to leaching. Research conducted on coarse-textured Mollisols in Argentina showed that $\mathrm{Cl}$ fertilization increased wheat grain yields in $50 \%$ of the sites. Averaged over 10 locations, the grain yield benefit due to chloride fertilization was $253 \mathrm{~kg}^{-1}$ and it was mostly explained by a greater number of grains per square meter (Díaz-Zorita, Duarte, and Baracco 2004). Soil Cl levels of $13.2 \mathrm{mg} \mathrm{kg}^{-1}$ were adequate 
for maximum grain yields (Díaz-Zorita, Duarte, and Barraco 2004). Research conducted in Canada between 1996 and 1998 on clay loam and fine sandy loam textured soils revealed that soil $\mathrm{Cl}$ levels were low in all years at the fine sandy loam site and in 1996 and 1998 at the clay loam site (Roberts 1999). Research in the Great Plains showed that $\mathrm{Cl}$ significantly increased wheat grain yields by as much as $1546 \mathrm{~kg} \mathrm{ha}^{-1}$ at three sites, increasing gross return by $\$ 50 \mathrm{ha}^{-1}$ (Lamond, Roberson, and Rector 1999). Generally, wheat grown in Cldeficient soils responded positively to $\mathrm{Cl}$ rates less than $50 \mathrm{~kg} \mathrm{ha}^{-1}$. Research findings suggest that soil $(0-25 \mathrm{~cm}) \mathrm{Cl}$ levels less than $33 \mathrm{~kg} \mathrm{ha}^{-1}$, will require $22 \mathrm{~kg} \mathrm{Cl} \mathrm{ha}^{-1}$ applied as $\mathrm{KCl}$ (Lamond and Leikam 2002). Further, the concentration of $\mathrm{Cl}$ in wheat should be $0.4 \%$ in the whole plant at the boot to flowering stage to achieve maximum yield potential (Lamond 2003). Research conducted in the Great Plains of the United States showed that yield response occurs about half the time when plant $\mathrm{Cl}$ is between 0.12 and $0.4 \%$, but it occurs $80 \%$ of the time when plant $\mathrm{Cl}$ concentrations are $0.12 \%$ or less (Lamond 2003). Similar results were also reported from research conducted in the Pacific Northwest regions of the United States, where $\mathrm{Cl}$ fertilization practices increased productivity of wheat and other crops (Grant, Lamond, and Mohr 2003; Engel et al. 1997).

One of the important functions of $\mathrm{Cl}$ as a whole is its significance in suppressing some foliar diseases. In this respect, several research findings were published (Miller and Jungman 1998; Engel and Grey 1991; Christensen et al. 1981) that documented the benefits of $\mathrm{Cl}$ fertilization in lowering the negative effects of disease during the development of the crops and the subsequent improvement in yield. In Texas, topdress applications of $\mathrm{Cl}$ have caused significant reduction of leaf rust and septoria ratings at bloom and significant yield responses. They found a strong positive and significant interaction between $\mathrm{Cl}$ and systemic foliar fungicides, which are commonly used in wheat (Miller and Jungman 1998).

Some researchers attribute the $\mathrm{Cl}$ effect to nondisease wheat growthlimiting factors (Engel, Ecknoff, and Berg 1994; Fixen 1993). According to these researchers, $\mathrm{Cl}$ fertilization is beneficial in preventing the occurrence of a leaf spot syndrome that is not disease related (Engel et al. 1997; Smiley, Gillespie-Sasse, et al., 1993). In support to their argument, they suggested that $48 \mathrm{~kg} \mathrm{ha}^{-1} \mathrm{Cl}$ fertilization decreased physiological leafspot on winter wheat in Saskatchewan.

Others claim that $\mathrm{Cl}$ may increase wheat grain yields by enhancing $\mathrm{NH}_{4}^{+}$ supply attributed to lower leaf osmotic potentials, delayed nitrification in the soil, and inhibition of take-all root rot (Gaeumannomyces graminis) disease (Christensen and Brett 1985; Koening and Pan 1996). This is an interesting aspect of $\mathrm{Cl}$ because this indicates that the uptake of major nutrients such as $\mathrm{N}$ depends on its availability in the soil. In fact, several researchers underlined $\mathrm{Cl}$ 's role in uptake of other nutrients, especially macronutrients such as $\mathrm{N}$.

In Oklahoma, research conducted for 8 years on the effect of $\mathrm{Cl}$ on wheat grain yield and take-all disease found that only in 2 years' yield was significantly 
affected by $\mathrm{Cl}$ levels (Thomason et al. 2001). This was apparently because of the high $\mathrm{Cl}$ level in the soil of the experimental site, which was a silty loam. Soil survey research across the state, however, revealed that about $32 \%$ of soil samples collected from 17 counties had $\mathrm{Cl}$ less than optimum for soil samples $60 \mathrm{~cm}$ deep (Zhang 2000). This means that in the topsoil where wheat roots are abundant, the nutrient is below optimum level. According to this report, in the surface soil $(15 \mathrm{~cm}), 98 \%$ of the samples showed response to $\mathrm{Cl}$ fertilization. Another 2-year and three-site study in Oklahoma showed an inconsistent response of wheat grain yield to applied $\mathrm{Cl}$ (Zhang and Raun 2004).

In today's wheat production in Oklahoma, farmers use mainly $\mathrm{N}$ and phosphorus ( $\mathrm{p}$ ) fertilizers that do not have $\mathrm{Cl}$. The practice of avoiding fertilizers containing metallic salts of $\mathrm{Cl}$ shows possible deficiency of $\mathrm{Cl}$ in soils for crop requirements, especially in high-yielding deep sandy soils with low organic matter (LaRuffa et al. 1999). According to the National Atmospheric Deposition Program (NADP), $\mathrm{Cl}$ deposition has been decreasing by $0.04 \mathrm{~kg}$ ha $^{-1}$ annually since 1983 (NADP 2003) as a result of various measures to reduce pollution. This indicates that $\mathrm{Cl}$ as a micronutrient needs to be studied for cropping systems and soil conditions of a given agro-ecology. Additionally, few studies were conducted to assess the effect of $\mathrm{Cl}$ on uptake of $\mathrm{N}$ by wheat. With this in mind, long-term $\mathrm{Cl}$ experiments were initiated in 1995 at two locations in different soils in Oklahoma to assess the response of winter wheat grain yield and $\mathrm{N}$ uptake to $\mathrm{Cl}$ fertilizer.

\section{MATERIALS AND METHODS}

Two experiments were conducted from 1996 to 2002 at Hennessey (Shellabarger sandy loam-fine loamy, mixed, thermic Udic Argiustolls) and Perkins (Teller sandy loam-fineloamy, mixed, thermic Udic Argiustolls), Oklahoma, to evaluate the response of winter wheat grain yield and $\mathrm{N}$ uptake to $\mathrm{Cl}$ fertilizer. The Hennessey location is a typical environment for wheat production in north central Oklahoma. The Perkins location is on a deep, sandy, low-organic-matter soil, which is more prone to leaching of mobile nutrients including $\mathrm{Cl}$ in soil solution. Initial soil test data are reported in Table 1. A one-to-one soil-to-water paste was used to extract initial soil $\mathrm{Cl}$ (Diamond 1994) and was quantified using a Lachat (Milwaukee, WI) flow injection analyzer.

A randomized complete block experimental design with three replications was used at both sites with three rates of 0,15 , and $30 \mathrm{~kg} \mathrm{Cl} \mathrm{ha}^{-1}$ using calcium chloride $\left(\mathrm{CaCl}_{2}\right)$. Plot sizes were $4.9 \mathrm{~m}$ by $6.1 \mathrm{~m}$.

The winter wheat variety Tonkawa was used during the 1996 to 1999 cropping seasons. This variety was replaced by Custer from 2000 to 2002. Wheat was planted between October and November for all experiments at a seeding rate of $98 \mathrm{~kg} \mathrm{ha}^{-1}$. All other crop management practices were carried out as per the recommendation of the respective sites. Wheat was 
Table 1. Initial soil chemical characteristics at Hennessy and Perkins sites in Oklahoma

\begin{tabular}{|c|c|c|c|c|c|c|c|}
\hline Location & $\mathrm{pH}$ & $\begin{array}{c}\mathrm{NH}_{4}-\mathrm{N} \\
\left(\mathrm{mg} \mathrm{kg}^{-1}\right)\end{array}$ & $\begin{array}{c}\mathrm{NO}_{3}-\mathrm{N} \\
\left(\mathrm{mg} \mathrm{kg}^{-1}\right)\end{array}$ & $\begin{array}{c}\mathrm{P} \\
\left(\mathrm{mg} \mathrm{kg}^{-1}\right)\end{array}$ & $\begin{array}{c}\mathrm{K} \\
\left(\mathrm{mg} \mathrm{kg}^{-1}\right)\end{array}$ & \multicolumn{2}{|c|}{$\begin{array}{c}\mathrm{Cl} \\
\left(\mathrm{mg} \mathrm{kg}^{-1}\right)\end{array}$} \\
\hline Hennessey & 5.8 & 19 & 14 & 142 & 674 & 12 & $12^{a}$ \\
\hline Perkins & 6.0 & 5 & 4 & 51 & 143 & 6 & $5^{a}$ \\
\hline
\end{tabular}

Notes: Samples were collected from the surface $(0-15 \mathrm{~cm})$ except for chloride, where additional samples were analyzed from the entire $0-60 \mathrm{~cm}$ depth.

$\mathrm{pH}$ and $\mathrm{Cl}, 1: 1$ soil-water extraction. $\mathrm{NH}_{4}-\mathrm{N}$ and $\mathrm{NO}_{3}-\mathrm{N}, 2 \mathrm{M} \mathrm{KCl}$ extraction. $\mathrm{P}$ and $\mathrm{K}$, Mehlich III extraction.

${ }^{a}$ Soil chloride level in the $0-60-\mathrm{cm}$ depth.

harvested from the center of each plot in June with a Massey Ferguson 8XP plot combine, removing an area of $2.0 \mathrm{~m}$ by $6.1 \mathrm{~m}$. A Harvest Master yieldmonitoring computer installed on the combine recorded yield data, and subsamples were collected. Grain samples were dried in a forced-air oven at $66^{\circ} \mathrm{C}$, ground to pass a 140 -mesh sieve $(100 \mu \mathrm{m})$, and analyzed for total $\mathrm{N}$ content using a Carlo-Erba 1500 dry combustion analyzer.

Grain yield data were subjected to statistical analysis using SAS (SAS Institute 2001). Polynomial orthogonal contrasts were used to detect trends in grain yield or $\mathrm{N}$ uptake in response to $\mathrm{Cl}$ levels.

\section{RESULTS AND DISCUSSION}

\section{Grain Yield}

Chloride rates significantly increased wheat grain yield in $50 \%$ of the yearsite combinations (Tables 2 and 3). At Hennessey in 1998, a quadratic trend

Table 2. Effect of chloride fertilizer $\left(\mathrm{CaCl}_{2}\right)$ on wheat grain yield $\left(\mathrm{Mg} \mathrm{ha}^{-1}\right)$ at Hennessey, Oklahoma

\begin{tabular}{lcccccccc}
\hline Parameter & 1996 & 1997 & 1998 & 1999 & 2000 & 2001 & 2002 & Average \\
\hline Cl: $0 \mathrm{Kg} \mathrm{ha}^{-1}$ & 2.47 & 2.07 & 4.10 & 2.31 & 4.25 & 2.20 & 3.50 & 3.00 \\
$\mathrm{Cl}^{2} 33.6 \mathrm{Kg} \mathrm{ha}^{-1}$ & 2.40 & 2.17 & 4.50 & 2.33 & 4.23 & 2.11 & 3.89 & 3.06 \\
Cl: $67.2 \mathrm{Kg} \mathrm{ha}^{-1}$ & 2.42 & 2.66 & 4.29 & 2.10 & 4.04 & 2.44 & 3.99 & 3.13 \\
SED contrast & 0.18 & 0.50 & 0.14 & 0.20 & 0.13 & 0.10 & 0.40 & 0.09 \\
Linear & $\mathrm{NS}$ & $\mathrm{NS}$ & $\mathrm{NS}$ & $\mathrm{NS}$ & $\mathrm{NS}$ & $*$ & $\mathrm{NS}$ & $\mathrm{NS}$ \\
Quadratic & $\mathrm{NS}$ & $\mathrm{NS}$ & $*$ & $\mathrm{NS}$ & $\mathrm{NS}$ & $\mathrm{NS}$ & $\mathrm{NS}$ & $\mathrm{NS}$ \\
\hline
\end{tabular}

Notes: NS, not significant. *, **, significant at the $10 \%, 5 \%$ levels, respectively. SED: standard error of the difference between two equally replicated means. 
Table 3. Effect of chloride fertilizer $\left(\mathrm{CaCl}_{2}\right)$ on wheat grain yield $\left(\mathrm{Mg} \mathrm{ha}^{-1}\right)$ at Perkins, Oklahoma

\begin{tabular}{lcccccccc}
\hline Parameter & 1996 & 1997 & 1998 & 1999 & 2000 & 2001 & 2002 & Average \\
\hline $\mathrm{Cl}^{0} 0 \mathrm{Kg} \mathrm{ha}^{-1}$ & 1.16 & 0.63 & 1.62 & 0.86 & 1.21 & 2.18 & 2.78 & 1.49 \\
$\mathrm{Cl}: 33.6 \mathrm{Kg} \mathrm{ha}^{-1}$ & 1.22 & 0.66 & 1.61 & 0.89 & 1.47 & 2.16 & 2.92 & 1.56 \\
$\mathrm{Cl}: 67.2 \mathrm{Kg} \mathrm{ha}^{-1}$ & 1.47 & 0.83 & 1.92 & 1.12 & 1.67 & 2.06 & 2.87 & 1.71 \\
SED contrast & 0.12 & 0.07 & 0.19 & 0.13 & 0.16 & 0.13 & 0.14 & 0.06 \\
Linear & $*$ & $* *$ & $\mathrm{NS}$ & $*$ & $* *$ & $\mathrm{NS}$ & $\mathrm{NS}$ & $* *$ \\
Quadratic & $\mathrm{NS}$ & $\mathrm{NS}$ & $\mathrm{NS}$ & $\mathrm{NS}$ & $\mathrm{NS}$ & $\mathrm{NS}$ & $\mathrm{NS}$ & $\mathrm{NS}$ \\
\hline
\end{tabular}

Notes: NS, not significant. ${ }^{*},{ }^{* *}$, significant at the $10 \%, 5 \%$ levels, respectively. SED: standard error of the difference between two equally replicated means.

was observed. The response at Hennessey in 1998 showed a common response trend of mobile nutrients such as $\mathrm{Cl}$. In 2001, wheat grain yield increased linearly with an increase in $\mathrm{Cl}$ levels. Even though not significant, an increasing linear trend in grain yield was observed at Hennessey in 1997 as well as in 2002. In contrast, in 2000 a decrease in yield was observed with an increase in $\mathrm{Cl}$ rate. The average increment in grain yield (cf. no $\mathrm{Cl}$ check) averaged over years was only 2 and $4 \%$, respectively for 33.6 and $67.2 \mathrm{~kg} \mathrm{ha}^{-1} \mathrm{Cl}$ rates. The increase in grain yield for some of the years might be attributed to nitrification inhibition in soils where $\mathrm{pH}$ was low as reported by previous research (Christensen and Brett 1985; Roseberg, Christensen, and Jackson 1986). The conditions that induce $\mathrm{Cl}$ response of crops in soils such as Hennessey are primarily rainfall and $\mathrm{pH}$. The initial soil $\mathrm{Cl}$ levels both on the surface $(0-$ $15 \mathrm{~cm}$ ) and at a depth of $0-60 \mathrm{~cm}$ (Table 1) were slightly lower than that required for optimum yield. This explains the irregularity in response observed at this location.

At Perkins, wheat grain yield was significantly influenced in four years (1996, 1997, 1999, and 2000) and the average of all years. In all cases, a linear response was observed where yield was increased with an increase in $\mathrm{Cl}$ rate. Over years, 33.6 and $67.2 \mathrm{~kg} \mathrm{ha}^{-1} \mathrm{Cl}$ fertilization resulted in 5.0 and $14.5 \%$ increment in grain yield. The fact that this site is characterized by a sandy loam soil might explain the linear response to $\mathrm{Cl}$. The initial soil test level of $6.0 \mathrm{mg} \mathrm{kg}^{-1}$ at this site was way below the $13.2 \mathrm{mg}$ $\mathrm{kg}^{-1}$ required for optimum grain yield when $\mathrm{Cl}$ is the most limiting nutrient. This partially explains why significant responses to $\mathrm{Cl}$ were obtained at Perkins. As an anion, $\mathrm{Cl}$ is not readily adsorbed on the soil exchange complex or organic matter and mostly present in the soil solution. Because of this, $\mathrm{Cl}$ moves readily with soil water and is more prone to loss in sandy soils. This results in a quick depletion of $\mathrm{Cl}$ deposited in the soil, resulting in deficiency and subsequent response of wheat to applied $\mathrm{Cl}$. 
Table 4. Effect of chloride fertilizer $\left(\mathrm{CaCl}_{2}\right)$ on grain $\mathrm{N}$ uptake $\left(\mathrm{Kg} \mathrm{ha}^{-1}\right)$ at Hennessey, Oklahoma

\begin{tabular}{lcccccccc}
\hline Parameter & 1996 & 1997 & 1998 & 1999 & 2000 & 2001 & 2002 & Average \\
\hline $\mathrm{Cl}: 0 \mathrm{Kg} \mathrm{ha}^{-1}$ & 77.6 & 68.4 & 107.3 & 58.6 & 99.4 & 54.9 & 98.0 & 80.9 \\
$\mathrm{Cl}: 33.6 \mathrm{Kg} \mathrm{ha}^{-1}$ & 77.2 & 73.8 & 120.6 & 57.7 & 99.5 & 56.0 & 109.3 & 83.8 \\
$\mathrm{Cl}: 67.2 \mathrm{Kg} \mathrm{ha}^{-1}$ & 74.6 & 86.6 & 115.6 & 52.2 & 99.3 & 62.6 & 108.7 & 85.7 \\
SED contrast & 5.5 & 15.8 & 4.7 & 5.3 & 8.3 & 3.3 & 10.8 & 2.9 \\
Linear & $\mathrm{NS}$ & $\mathrm{NS}$ & $\mathrm{NS}$ & $\mathrm{NS}$ & $\mathrm{NS}$ & $\mathrm{NS}$ & $\mathrm{NS}$ & $*$ \\
Quadratic & $\mathrm{NS}$ & $\mathrm{NS}$ & $*$ & $\mathrm{NS}$ & $\mathrm{NS}$ & $* *$ & $\mathrm{NS}$ & $\mathrm{NS}$ \\
\hline
\end{tabular}

NS, not significant. ${ }^{*},{ }^{* *}$, significant at the $10 \%, 5 \%$ levels, respectively. SED: standard error of the difference between two equally replicated means

The results from this site clearly shows that sandy loam soils in Oklahoma need to be supplemented with $\mathrm{Cl}$ especially if potassium is inherently available and if calcium is not applied to the soils, because the fertilizer form of these two nutrients contain $\mathrm{Cl}$. This is an important part of wheat management because farmers tend to supply wheat mainly with $\mathrm{N}$ and $\mathrm{P}$ fertilizers and not potassium, leading to $\mathrm{Cl}$ deficiency in those soils. The results obtained here are also in agreement with previous research reports (Thomason et al. 2001; Koening and Pan 1996; Zhang 2000).

\section{Grain Nitrogen Uptake}

Chloride levels affected this variable in 2 of 7 years at Hennessey, in 1 of 7 years at Perkins (Tables 4 and 5), and the average of years at both locations. In 2001 at Hennessey and in 2000 at Perkins, a significant linear response in grain $\mathrm{N}$ uptake was obtained with increasing rates of $\mathrm{Cl}$, while a quadratic response was obtained at Hennessy in 1998. In 1996 and 1999 at Hennessey, the $\mathrm{N}$ uptake decreased linearly but insignificantly with

Table 5. Effect of chloride fertilizer $\left(\mathrm{CaCl}_{2}\right)$ on grain $\mathrm{N}$ uptake $\left(\mathrm{Kg} \mathrm{ha}^{-1}\right)$ at Perkins, Oklahoma

\begin{tabular}{|c|c|c|c|c|c|c|c|c|}
\hline Parameter & 1996 & 1997 & 1998 & 1999 & 2000 & 2001 & 2002 & Average \\
\hline $\mathrm{Cl}: 0 \mathrm{Kg} \mathrm{ha}^{-1}$ & 28.6 & $\mathrm{~N} / \mathrm{A}$ & 29.1 & 17.8 & 21.2 & 54.4 & 66.0 & 35.7 \\
\hline $\mathrm{Cl}: 33.6 \mathrm{Kg} \mathrm{ha}^{-1}$ & 28.2 & $\mathrm{~N} / \mathrm{A}$ & 31.1 & 19.3 & 26.0 & 55.3 & 70.4 & 38.4 \\
\hline $\mathrm{Cl}: 67.2 \mathrm{Kg} \mathrm{ha}^{-1}$ & 36.0 & $\mathrm{~N} / \mathrm{A}$ & 36.8 & 21.3 & 29.8 & 52.8 & 69.2 & 41.0 \\
\hline SED contrast & 4.5 & $\mathrm{~N} / \mathrm{A}$ & 5.6 & 3.3 & 4.0 & 3.1 & 5.0 & 1.4 \\
\hline Linear & NS & $\mathrm{N} / \mathrm{A}$ & NS & NS & $*$ & NS & NS & $* *$ \\
\hline Quadratic & NS & $\mathrm{N} / \mathrm{A}$ & NS & NS & NS & NS & NS & NS \\
\hline
\end{tabular}

Notes: NS, not significant. *, **, significant at the $10 \%, 5 \%$ levels, respectively. SED: standard error of the difference between two equally replicated means. 
increasing $\mathrm{Cl}$ application rates, whereas $\mathrm{N}$ uptake increased linearly in 1998 and 1999 at Perkins. Although significant differences in $\mathrm{N}$ uptake due to $\mathrm{Cl}$ fertilization were found only in 3 of the 14 experiments, 7 experiments showed a linear increase, and 5 of them showed an increasing and then a decreasing quadratic response. Overall, application of 33.6 and $67.2 \mathrm{~kg} \mathrm{ha}^{-1}$ $\mathrm{Cl}$ at the Hennessey site resulted in 3.5 and $5.6 \%$ grain $\mathrm{N}$ uptake, respectively, compared with the no $\mathrm{Cl}$ check. At Perkins, the two $\mathrm{Cl}$ rates resulted in 7.5 and $14.8 \%$ increase in grain $\mathrm{N}$ uptake. This suggests that $\mathrm{Cl}$ has a direct or indirect effect on $\mathrm{N}$ uptake by wheat crop. This could be due to an antagonistic effect of $\mathrm{Cl}_{\text {on }} \mathrm{NO}_{3}^{-}$in the leaf tissue, which might have affected $\mathrm{N}$ uptake in grain as reported by previous research (Christensen and Brett 1985). The physiological basis of this response, however, needs to be further studied.

\section{REFERENCES}

Broyer, T.C., Carlton, A.B., Johnson, A.B., and Stout, P.R. (1954) Chlorine: A micronutrient element for higher plants. Plant Physiology, 29: 526-532.

Carr, P.M., Martin, G.B., and Melchior, B.A. (2001) Spring Wheat Response to Chloride Applications in Southwestern North Dakota; Agronomy Section 2001 Annual Report. Dickinson Research and Extension Center: Dickinson, North Dakota.

Christensen, N.W. and Brett, M. (1985) Chloride and liming effects on soil nitrogen form and take-all of wheat. Agronomy Journal, 77: 157-163.

Christensen, N.W., Taylor, R.G., Jackson, T.L., and Mitchell, B.L. (1981) Chloride effects on water potentials and yield of winter wheat infected with take-all root rot. Agronomy Journal, 73: 1053-1058.

Diamond, D. (1994) Determination of chloride by flow injection analysis colorimetry. QuikChem Method 10-117-07-1-B; Lachat Instruments: Milwaukee, Wisconsin.

Díaz-Zorita, M., Duarte, G.A., and Barraco, M. (2004) Effects of chloride fertilization on wheat (Triticum aestivum L.) productivity in the sandy Pampas region, Argentina. Agronomy Journal, 96 (3): 839-844.

Engel, R.E., Bruebaker, L., and Emborg, T.J. (2001) A chloride deficient leaf spot of durum wheat. Soil Science Society of America Journal, 65 (5): 1448-1454.

Engel, R.E. and Grey, W.E. (1991) Chloride fertilizer effects on winter wheat inoculated with Fusarium culmorum. Agronomy Journal, 83: 204-208.

Engel, R.E., Ecknoff, J., and Berg, R.K. (1994) Grain yield, kernel weight, and disease responses of winter wheat cultivars to chloride fertilization. Agronomy Journal, 86: 891- 1986.

Engel, R.E., Bruckner, P.L., Mathre, D.E., and Brumfield, S.K.Z. (1997) A chloridedeficient leaf spot syndrome of wheat. Soil Science Society of America Journal, 61: $176-184$.

Fixen, P.E. (1993) Crop responses to chloride. Advances in Agronomy, 50: 107-150.

Grant, C.A., McLaren, D.L., and Johnston, A.M. (2001) Spring wheat cultivar response to potassium chloride fertilization. Better Crops, 85 (4): 20-23.

Grant, C.A., Lamond, R., and Mohr, R.M. (2003) Chloride research: What have we learned? In 2003 ASA-CSSA-SSSA Annual Meetings Abstracts [CD-ROM]. American Society of Agronomy, Crop Science Society of America, and Soil Science Society of America: Madison, Wisconsin. 
Kafkafi, U. and Xu, G. (2002) Chlorine. In Encyclopedia of Soil Science; Lal, R. (ed.), Marcel Dekker, Inc: New York, 152-155.

Koening, R.T. and Pan, W.L. (1996) Chloride enhancement of wheat responses to ammonium nutrition. Soil Science Society of America Journal, 60: 468-505.

Lamond, R. (2003) How do we manage chloride? In 2003 ASA-CSSA-SSSA Annual Meetings Abstracts [CD-ROM]. American Society of Agronomy, Crop Science Society of America, and Soil Science Society of America: Madison, Wisconsin.

Lamopnnd, R.E. and Leikam, D.F. (2002) Kansas state university agricultural experiment station and cooperative extension service MF-2570. In Chloride in Kansas: Plant, Soil, and Fertilizer Considerations. Kansas State University: Manhattan, Kansas.

Lamond, R.E., Roberson, D.D., and Rector, K. (1999) Chloride fertilization bumps wheat yields and profits. Fluid Journal, 7 (27): 14-15.

LaRuffa, J.M., Johnson, G.V., Phillips, S.B., and Raun, W.R. (1999) Sulfur and chloride response in Oklahoma winter wheat. Better Crops, 32 (4): 28-30.

Miller, T. (1998) Chloride fertilizer effects in winter wheat and interactions with foliar fungicides under severe leaf rust pressure. Better Crops, 82 (1): 24-25.

Miller, T. and Jungman, M. (1998) Chloride fertilizer in winter wheat: Effect of $\mathrm{Cl}$ and interactions with foliar fungicides under severe leaf rust pressure. In. Proceedings of Intensive Wheat Management Conference; Texas Agricultural extension Service. The Texas A\&M University System: College Station, Texas.

National Atmospheric Deposition Program (NADP). In National Atmospheric Deposition Program 2002 annual summary; NADP Data Report 2003-01. NADP: Champaign, Illinois.

Ozanne, P.G., Woolley, J.T., and Broyer, T.C. (1957) Chlorine and bromine in the nutrition of higher plants. Australian Journal of Biological Science, 10: 66-79.

Roberts, T.L. (1999) Chloride: Can we close the book? Potash \& Phosphate Institute and Potash \& Phosphate Institute of Canada: Saskatoon Saskatchewan, Canada.

Roseberg, R.J., Christensen, N.W., and Jackson, T.L. (1986) Chloride, soil solution osmotic potential, and soil $\mathrm{pH}$ effects on nitrification. Soil Science Society of America Journal, 50: 941-945.

SAS Institute. (2001) The SAS System for Windows, Version 8.02; SAS Institute 2001: Cary, North Carolina.

Sillanpää, M. (1982) Micronutrients and the Nutrient Status of the Soils: A Global Study; Food and Agriculture Organization (FAO): Rome, Italy.

Smiley, R.W., Gillespie-Sasse, L.M., Uddin, W., Collins, H.P., and Stoltz, M. (1993) A physiologic leaf spot of winter wheat. Plant Disease, 77: 521-527.

Smiley, R.W., Uddin, W., Zwer, P.K., Wysocki, D.J., Ball, D.A., and Chastain, T.G. (1993) Influence of crop management practice on physiologic leaf spot of winter wheat. Plant Disease, 77: 803-810.

Thomason, W.E., Wynn, K.J., Freeman, K.W., Lukina, E.V., Mullen, R.W., Johnson, G.V., Westerman, R.L., and Raun, W.R. (2001) Effect of chloride fertilizers and lime on wheat grain yield and take-all disease. Journal of Plant Nutrition, 24 (4\&5): 683-692.

Wallace, T. (1944) The Diagnosis of Mineral Deficiencies in Plants by Visual Symptoms; Her Majesty's Stationery Office: London, U.K.

Zhang, H. (2000) Soil chloride, nitrate and sulfate in Oklahoma soils. In Soil Fertility Research Highlights; Oklahoma State University: Stillwater, Oklahoma, 329-331.

Zhang, H. and Raun, W.R. (2004) Soil chloride and sulfate status in Oklahoma soils. In. In Proceedings of the Southern Plant Nutrient Management Conference; Crozier, C. (ed.), Samuel Roberts Noble Foundation: Ardmore, Oklahoma, 97-100. 